Check for updates

Cite this: RSC Adv., 2017, 7, 24940

Received 22nd March 2017 Accepted 24th April 2017

DOI: 10.1039/c7ra03345a

rsc.li/rsc-advances

\section{Iridoids and bis-iridoids from Patrinia scabiosaefolia $\uparrow$}

\author{
Zhen-Hua Liu, ${ }^{\text {ab }}$ Bo Hou, ${ }^{\text {ab }}$ Liu Yang, ${ }^{a}$ Rui-Jing Ma, ${ }^{\text {ab }}$ Jin-Yu Li, ${ }^{\text {ab }}$ Jiang-Miao Hu ${ }^{\star a}$ \\ and Jun Zhou*a
}

Ten new iridoids, patriscabioins A-J (1-10), and three unique bis-iridoids, patriscabiobisins A-C (11-13), together with seven known analogues, have been identified from whole plants of Patrinia scabiosaefolia. Compounds 1 to 8 are a series of 5,6-dihydrovaltrate hydrins with unique substituent groups in the Valerianaceae family such as isovaleryl and 3-methylcrotonyl. Furthermore, compounds 11 and 12 are the first reported bis-iridoids with two units connected by a 1,3-dioxane group, whereas compound 13 is linked by an ether bond between two units. The structures of all the compounds were established on the basis of extensive spectroscopic analysis as well as experimental and calculated ECD spectra. Compounds 1 and 3 showed moderate inhibitory activities on AChE with $I_{50}$ values of 37.6 and 10.5 $\mu \mathrm{M}$, respectively. Moreover, compounds 1,3 , and 5 also showed moderate cytotoxic activity against $\mathrm{HL}-$ 60 , with $I C_{50}$ values ranging from 1.2 to $27.6 \mu \mathrm{M}$.

\section{Introduction}

Iridoids, which derive their name from iridomyrmecin, iridolactone and iridodial, usually contain a bicyclic $\mathrm{H}-5 / \mathrm{H}-9 \beta, \beta$-cisfused cyclopentan pyran ring. Iridoids are found in a large number of folk medicinal plants. Cleaving the cyclopentan or pyran ring results in derivatives called secoiridoids. Iridoids and secoiridoids have remarkable biological activities such as antiallergic, antiarthritic, anti-inflammatory, antispasmodic, antibacterial, antifungal, antiviral, antiprotozoal, anticancer, anticoagulant, antioxidant, neuroprotective, and nerve growth factor-potentiating; thus, they are currently attracting increasing attention. ${ }^{1-4}$ Furthermore, iridoids are regarded as the bioactive compounds in some plants used in traditional medicines and are also considered to be chemotaxonomic markers in some cases such as the revision of Asteridae in 1959. ${ }^{5}$

Previous phytochemical investigations on genus Patrinia (Valerianaceae) showed that these plants contain many iridoids and their saponins. ${ }^{6}$ Patrinia scabiosaefolia is a perennial herb that is distributed widely across China, except for the provinces of Ningxia, Qinghai, Xinjiang, Tibet and Hainan Island; it is used in sedation, antibacterial, and antiviral applications. ${ }^{7}$ In order to enrich our knowledge of iridoids and further explore

${ }^{a}$ State Key Laboratory of Phytochemistry and Plant Resources in West China, Kunming Institute of Botany, Chinese Academy of Sciences, Kunming 650204, People's Republic of China. E-mail: yxcheng@mail.kib.ac.cn; Fax: +86-871-65223048; Tel: +86-87165223048

${ }^{b}$ University of Chinese Academy of Sciences, Yuquan Road 19, Beijing 100049, People's Republic of China

† Electronic supplementary information (ESI) available: 1D, 2DNMR, and MS spectra, crystallographic data, MTT assay. See DOI: 10.1039/c7ra03345a their bioactivities, the ethyl acetate extracts of whole plants of $P$. scabiosaefolia were investigated. This resulted in the isolation of ten new iridoids (1-10) and three unique bis-iridoids (11-13) along with seven known iridoids, confirmed to be stenopterin A (14), ${ }^{8}$ jatamanvaltrate P $(\mathbf{1 5}),{ }^{9}(1 S, 3 R, 5 S, 7 S, 8 S, 9 S)$-3,8-epoxy-7hydroxy-1-butoxy-4,11-dihyronepetane $\quad(\mathbf{1 6}),{ }^{10} \quad(1 S, 3 R, 5 S$, 7S,8S,9S)-3,8-epoxy-7-hydroxy-1-methoxy-4,11-dihyronepetane (17), ${ }^{10}$ jatamanin A (18), ${ }^{11}$ 6-hydroxy-7-(hydroxymethyl)-4-methylenehexahydro-cyclopenta[c]pyran-1 $(3 H)$-one $(19),{ }^{12}$ and villosol (20). ${ }^{13}$ In addition, all the new compounds were evaluated for their inhibitory activities on acetylcholine esterase (AChE). Meanwhile, considering the cytotoxicity of iridoids, ${ }^{14}$ we also tested the cytotoxicities of the new compounds against four human tumor cell lines (HL-60, SMMC-7721, MCF-7, and SW480). Herein, we describe the isolation, structure elucidation,

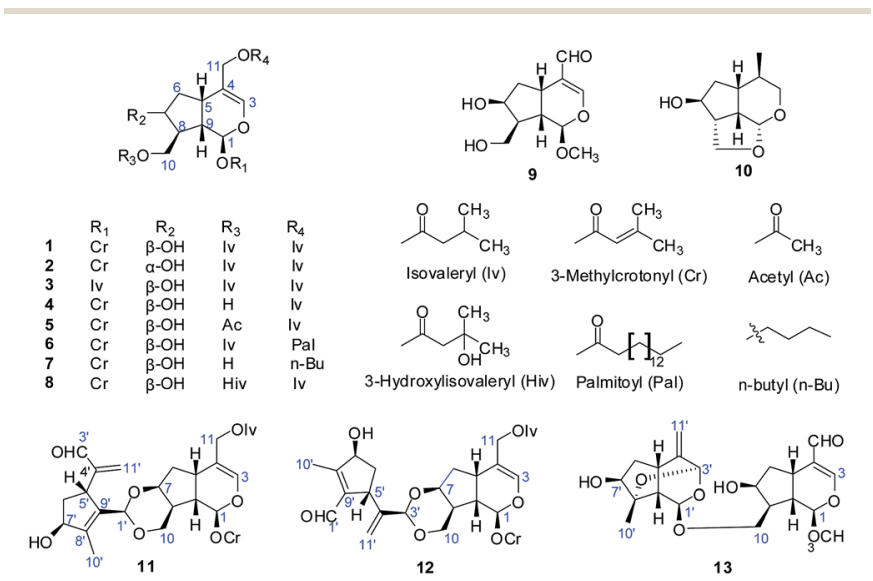

Fig. 1 The chemical structures of compounds 1-13. 
and biological evaluation of these new iridoids and bis-iridoids (Fig. 1).

\section{Results and discussion}

\subsection{Structure elucidation}

The EtOH extract of $P$. scabiosaefolia was suspended in $\mathrm{H}_{2} \mathrm{O}$ and partitioned with EtOAc. The EtOAc extract was repeatedly chromatographed to yield 20 iridoids, including ten new iridoids, patriscabioins A-J (1-10), and three new bis-iridoids, patriscabiobisins A-C (11-13).

Compound 1 was obtained as a light yellow oil, which was analyzed and determined to have the molecular formula $\mathrm{C}_{25} \mathrm{H}_{38} \mathrm{O}_{8}$ based on HRESIMS at $m / z$ 489.2454 [M $\left.+\mathrm{Na}\right]^{+}$(calcd 489.2459) and its ${ }^{13} \mathrm{C}$ NMR spectrum. The ${ }^{1} \mathrm{H}$ and ${ }^{13} \mathrm{C}$ spectroscopic data (Tables 1 and 3) showed a hemiketal methine at $\delta_{\mathrm{H}}$ $5.86(1 \mathrm{H}, \mathrm{d}, J=5.6 \mathrm{~Hz}, \mathrm{H}-1)$ and $\delta_{\mathrm{C}} 91.5(\mathrm{~d}, \mathrm{C}-1)$; a trisubstituted olefinic bond at $\delta_{\mathrm{H}} 6.38(1 \mathrm{H}, \mathrm{s}, \mathrm{H}-3), \delta_{\mathrm{C}} 140.2(\mathrm{~d}, \mathrm{C}-3)$, and $\delta_{\mathrm{C}}$ 113.7 (s, C-4); two oxygenated methylenes at $\delta_{\mathrm{C}} 62.5(\mathrm{t}, \mathrm{C}-10)$ and $\delta_{\mathrm{C}} 63.6(\mathrm{t}, \mathrm{C}-11)$; and an oxymethine at $\delta_{\mathrm{C}} 71.1(\mathrm{C}-7)$. The above data clearly suggest 1 to be a 7,10,11-trihydroxy-3-ene iridoid with ten carbons in its skeleton. ${ }^{8}$ Careful analysis of the ${ }^{13} \mathrm{C}$ NMR and 2D NMR spectra led to the discovery of two isovaleryl substituents at $\delta_{\mathrm{C}} 174.1(\mathrm{~s}), \delta_{\mathrm{C}} 43.4(\mathrm{t}), \delta_{\mathrm{C}} 25.7(\mathrm{~d}), \delta_{\mathrm{C}} 22.4(\mathrm{q}), \delta_{\mathrm{C}}$ $22.4(\mathrm{q})$ as well as $\delta_{\mathrm{C}} 173.0(\mathrm{~s}), \delta_{\mathrm{C}} 43.3(\mathrm{t}), \delta_{\mathrm{C}} 25.7(\mathrm{~d}), \delta_{\mathrm{C}} 22.3(\mathrm{q})$, $\delta_{\mathrm{C}} 22.3(\mathrm{q})$. In addition, a 3-methylcrotonyl group was discovered at $\delta_{\mathrm{C}} 164.8(\mathrm{~s}), \delta_{\mathrm{C}} 160.0(\mathrm{~s}), \delta_{\mathrm{C}} 115.1(\mathrm{~d}), \delta_{\mathrm{C}} 27.6(\mathrm{q}), \delta_{\mathrm{C}} 20.5$ (q). ${ }^{14}$ The 3-methylcrotonyl group should be attached to C-1 on the basis of HMBC correlation from $\mathrm{H}-1\left(\delta_{\mathrm{H}} 5.86\right)$ to the ester carbonyl carbon $\left(\delta_{\mathrm{C}} 164.8\right)$. The correlations from $\mathrm{H}-10\left(\delta_{\mathrm{H}} 4.10\right.$,
4.52) to one isovaleryl substituent at $\delta_{\mathrm{C}} 174.1$ (s) and from $\mathrm{H}-11$ $\left(\delta_{\mathrm{H}} 4.57,4.40\right)$ to the other isovaleryl at $\delta_{\mathrm{C}} 173.0(\mathrm{~s})$ in HMBC suggested that the two isovaleroxy substituents were positioned at C-10 and C-11, respectively (Fig. 2).

The absolute configurations of C-1 and C-9 were both $S$, as found in all naturally occurring valepotriates. ${ }^{15}$ Thus, the $\alpha$-orientations of $\mathrm{H}-7$ and $\mathrm{H}-8$ were determined by the ROESY correlations of $\mathrm{H}-1$ with $\mathrm{H}-7$ and $\mathrm{H}-8$. Additionally, the relative configuration of $\mathrm{H}-5$ was $\beta$-orientation, as deduced by the correlations from $\mathrm{H}-9$ to $\mathrm{H}-5$ in the ROESY experiments. Thus, the structure of $\mathbf{1}$ was elucidated as $(1 S, 5 S, 7 S, 8 S, 9 S)$-1-O-(3-methylcrotonyl)-7-hydroxy10,11-diisovaleroxy-5,6-dihydrovaltrate hydrin, named patriscabioin A (Fig. 3).

Compound 2 possessed the same molecular formula as compound $1, \mathrm{C}_{25} \mathrm{H}_{38} \mathrm{O}_{8}$, based on HRESIMS at $m / z$ 489.2462 [M + $\mathrm{Na}^{+}$(calcd 489.2459). The ${ }^{13} \mathrm{C}$ and ${ }^{1} \mathrm{H}$ NMR spectroscopic features were consistent with $\mathbf{1}$ but with a difference in the oxymethine signal at $\delta_{\mathrm{C}} 75.4(\mathrm{~d}, \mathrm{C}-7)$, which was higher than that in compound $1\left(\delta_{\mathrm{C}} 71.1, \mathrm{~d}, \mathrm{C}-7\right)$. Meanwhile, there are some differences between compounds 1 and 2 at C-6, C-8, and C-10 in their ${ }^{13} \mathrm{C}$ NMR spectra. Because the positions of the two isovaleryl substituents and the 3-methylcrotonyl group were the same, it can be speculated that the configuration of $\mathrm{C}-7$ is $\alpha$-orientation; this was proved by the correlations of $\mathrm{H}-7$ with $\mathrm{H}-6 \beta$ and $\mathrm{H}-6 \beta$ with $\mathrm{H}-5$ and $\mathrm{H}-9$ in the ROESY experiments. Hence, the structure of 2 was determined as $(1 S, 5 S, 7 R, 8 S, 9 S)$-1-O-(3-methylcrotonyl)-7hydroxy-10,11-diisovaleroxy-5,6-dihydrovaltrate hydrin; this compound was named patriscabioin B.

Compound 3 gave a molecular formula of $\mathrm{C}_{25} \mathrm{H}_{40} \mathrm{O}_{8}$, deduced from HRESIMS at $m / z$ 491.2607 $[\mathrm{M}+\mathrm{Na}]^{+}$(calcd

Table $1{ }^{1} \mathrm{H}$ NMR data of compounds $1-5$ ( $\delta$ in ppm, $\mathrm{J}$ in $\left.\mathrm{Hz}\right)$ in $\mathrm{CDCl}_{3}$

\begin{tabular}{|c|c|c|c|c|c|}
\hline No. & $\mathbf{1}^{a}$ & $2^{b}$ & $3^{b}$ & $4^{b}$ & $5^{b}$ \\
\hline 1 & $5.86(\mathrm{~d}, 5.6)$ & $5.86(\mathrm{~d}, 4.8)$ & $5.84(\mathrm{~d}, 5.5)$ & $5.86(\mathrm{~d}, 5.6)$ & $5.86(\mathrm{~d}, 5.8)$ \\
\hline 3 & $6.38(\mathrm{~s})$ & $6.40(\mathrm{~s})$ & $6.37(\mathrm{~s})$ & $6.39(\mathrm{~s})$ & $6.39(\mathrm{~s})$ \\
\hline $6 a$ & $2.13(\mathrm{~m})$ & $2.14(\mathrm{~m})$ & $2.15(\mathrm{~m})$ & $2.02(\mathrm{~m})$ & $2.13(\mathrm{~m})$ \\
\hline $6 b$ & $1.67(\mathrm{~m})$ & $1.87(\mathrm{~m})$ & $1.68(\mathrm{~m})$ & $1.81(\mathrm{~m})$ & $1.68(\mathrm{~m})$ \\
\hline 7 & $4.15(t, 3.5)$ & 5.34 (br s) & $4.16(\mathrm{t}, 3.4)$ & $4.45(\mathrm{~m})$ & $4.19(\mathrm{t}, 4.3)$ \\
\hline $10 \mathrm{a}$ & $4.10(\mathrm{dd}, 11.4,4.8)$ & $4.10(\mathrm{dd}, 11.4,4.6)$ & $4.10(\mathrm{dd}, 11.4,4.6)$ & $3.97(\mathrm{dd}, 11.2,3.5)$ & $4.13(\mathrm{dd}, 11.4,4.9)$ \\
\hline $10 \mathrm{~b}$ & $4.52(\mathrm{dd}, 11.4,9.9)$ & $4.54(\mathrm{~d}, 10.7)$ & $4.51(\mathrm{dd}, 11.4,10.0)$ & $3.81(\mathrm{dd}, 11.2,6.8)$ & $4.49(\mathrm{dd}, 11.4,9.8)$ \\
\hline $11 \mathrm{a}$ & $4.57(\mathrm{~d}, 12.3)$ & $4.58(\mathrm{~d}, 12.2)$ & $4.57(\mathrm{~d}, 12.3)$ & $4.60(\mathrm{~d}, 12.2)$ & $4.57(\mathrm{~d}, 12.3)$ \\
\hline $11 b$ & $4.40(\mathrm{~d}, 12.3)$ & $4.42(\mathrm{~d}, 12.2)$ & $4.41(\mathrm{~d}, 12.3)$ & $4.38(\mathrm{~d}, 12.2)$ & $4.41(\mathrm{~d}, 12.3)$ \\
\hline $\mathrm{R}_{1}-2^{\prime}$ & $5.70(\mathrm{~s})$ & $5.71(\mathrm{~s})$ & $2.19(\mathrm{~m})$ & $5.68(\mathrm{~s})$ & $5.70(\mathrm{~s})$ \\
\hline $3^{\prime}$ & & & $2.09(\mathrm{~m})$ & & \\
\hline $4^{\prime \prime}$ & $0.95(d, 5.6)$ & $0.96(\mathrm{~d}, 5.5)$ & $0.96(\mathrm{~d}, 3.1)$ & & \\
\hline $5^{\prime \prime}$ & $0.95(\mathrm{~d}, 5.6)$ & $0.96(\mathrm{~d}, 5.5)$ & $0.96(\mathrm{~d}, 3.1)$ & & \\
\hline $\mathrm{R}_{4}-2^{\prime \prime \prime}$ & $2.17(\mathrm{~d}, 8.9)$ & $2.19(\mathrm{~d}, 9.4)$ & $2.22(\mathrm{~m})$ & $2.16(\mathrm{~d}, 8.3)$ & 2.18 (d 8.3) \\
\hline $3^{\prime \prime \prime}$ & $2.08(\mathrm{~m})$ & $2.08(\mathrm{~m})$ & $2.09(\mathrm{~m})$ & $2.07(\mathrm{~m})$ & $2.10(\mathrm{~m})$ \\
\hline $4^{\prime \prime \prime}$ & $0.94(\mathrm{~d}, 5.6)$ & $0.96(\mathrm{~d}, 5.5)$ & $0.94(\mathrm{~d}, 2.6)$ & $0.95(\mathrm{~d}, 6.7)$ & $0.95(\mathrm{~d}, 6.6)$ \\
\hline $5^{\prime \prime \prime}$ & $0.94(\mathrm{~d}, 5.6)$ & $0.96(\mathrm{~d}, 5.5)$ & $0.94(\mathrm{~d}, 2.6)$ & $0.95(\mathrm{~d}, 6.7)$ & $0.95(\mathrm{~d}, 6.6)$ \\
\hline
\end{tabular}

${ }^{a}{ }^{1} \mathrm{H}$ NMR data recorded at $400 \mathrm{MHz} .{ }^{b}{ }^{1} \mathrm{H}$ NMR data recorded at $500 \mathrm{MHz}$. 
Table $2{ }^{1} \mathrm{H}$ NMR data of compounds 6-10 ( $\delta$ in ppm, $\mathrm{J}$ in $\left.\mathrm{Hz}\right)$ in $\mathrm{CDCl}_{3}$

\begin{tabular}{|c|c|c|c|c|c|}
\hline No. & $6^{c}$ & $7^{b}$ & $8^{c}$ & $9^{b}$ & $10^{a}$ \\
\hline 1 & $5.87(\mathrm{~d}, 5.5)$ & $5.87(\mathrm{~d}, 5.5)$ & $5.88(\mathrm{~d}, 5.6)$ & $4.65(\mathrm{~d}, 6.0)$ & $4.80(\mathrm{~d}, 2.0)$ \\
\hline $3 \mathrm{a}$ & $6.40(\mathrm{~s})$ & $6.29(\mathrm{~s})$ & $6.41(\mathrm{~s})$ & $7.21(\mathrm{br} \mathrm{s})$ & $4.09(\mathrm{~d}, 9.2)$ \\
\hline 4 & & & & & $2.05(\mathrm{~m})$ \\
\hline 5 & $3.00(\mathrm{q}, 7.8)$ & $2.95(\mathrm{q}, 7.4)$ & $2.99(\mathrm{q}, 6.8)$ & $3.16(\mathrm{q}, 8.2)$ & 1.73 (br s) \\
\hline $6 a$ & $2.16(\mathrm{~m})$ & $2.03(\mathrm{~m})$ & $2.13(\mathrm{~m})$ & $2.30(\mathrm{~m})$ & $1.90(\mathrm{~m})$ \\
\hline 8 & $2.07(\mathrm{~m})$ & $2.02(\mathrm{~m})$ & $2.12(\mathrm{~m})$ & $1.97(\mathrm{~m})$ & $2.67(\mathrm{~m})$ \\
\hline 9 & $2.20(\mathrm{~m})$ & $2.40(\mathrm{~m})$ & $2.21(\mathrm{~m})$ & $2.32(\mathrm{~m})$ & $2.16(\mathrm{~m})$ \\
\hline $10 \mathrm{a}$ & $4.53(\mathrm{~d}, 10.9)$ & $3.97(\mathrm{dd}, 11.2,8.3)$ & $4.52(\mathrm{dd}, 11.2,9.8)$ & $3.96(\mathrm{dd}, 11.2,4.2)$ & $4.15(\mathrm{dd}, 8.3,2.6)$ \\
\hline $10 \mathrm{~b}$ & $4.11(\mathrm{dd}, 11.2,4.0)$ & $3.82(\mathrm{dd}, 11.2,3.7)$ & $4.41(\mathrm{dd}, 11.2,4.9)$ & $3.82(\mathrm{dd}, 11.2,6.5)$ & $3.87(\mathrm{dd}, 8.3,3.5)$ \\
\hline $11 \mathrm{a}$ & $4.58(\mathrm{~d}, 12.2)$ & $3.95(\mathrm{~d}, 11.8)$ & $4.59(\mathrm{~d}, 12.3)$ & $9.29(\mathrm{~s})$ & $1.05(\mathrm{~d}, 6.9)$ \\
\hline $11 b$ & $4.41(\mathrm{~d}, 12.2)$ & $3.74(\mathrm{~d}, 11.8)$ & $4.41(\mathrm{~d}, 12.3)$ & & \\
\hline $3^{\prime \prime}$ & $2.09(\mathrm{~m})$ & & & & \\
\hline $4^{\prime \prime}$ & $0.96(\mathrm{~d}, 6.5)$ & & $1.25(\mathrm{~s})$ & & \\
\hline $5^{\prime \prime}$ & $0.96(\mathrm{~d}, 6.5)$ & & $1.31(\mathrm{~s})$ & & \\
\hline \multirow[t]{2}{*}{$\mathrm{R}_{4}-2^{\prime \prime \prime}$} & $2.33(\mathrm{~m})$ & $3.37(\mathrm{~m})$ & $2.19(\mathrm{~d}, 9.3)$ & & \\
\hline & & $3.30(\mathrm{~m})$ & & & \\
\hline $3^{\prime \prime \prime}$ & $1.58(\mathrm{~m})$ & $1.53(\mathrm{~m})$ & $2.10(\mathrm{~m})$ & & \\
\hline $4^{\prime \prime \prime}$ & $1.25(\mathrm{~m})$ & $1.35(\mathrm{~m})$ & $0.96(\mathrm{~d}, 6.6)$ & & \\
\hline $5^{\prime \prime \prime}$ & $1.25(\mathrm{~m})$ & $0.91(t, 7.4)$ & $0.96(\mathrm{~d}, 6.6)$ & & \\
\hline
\end{tabular}

${ }^{a}{ }^{1} \mathrm{H}$ NMR data recorded at $400 \mathrm{MHz} .{ }^{b}{ }^{1} \mathrm{H}$ NMR data recorded at $500 \mathrm{MHz} .{ }^{c 1} \mathrm{H}$ NMR data recorded at $600 \mathrm{MHz}$.

Table $3{ }^{13} \mathrm{C}$ NMR data of compounds $1-10$ ( $\delta$ in ppm, $\mathrm{J}$ in $\mathrm{Hz}$ ) in $\mathrm{CDCl}_{3}$

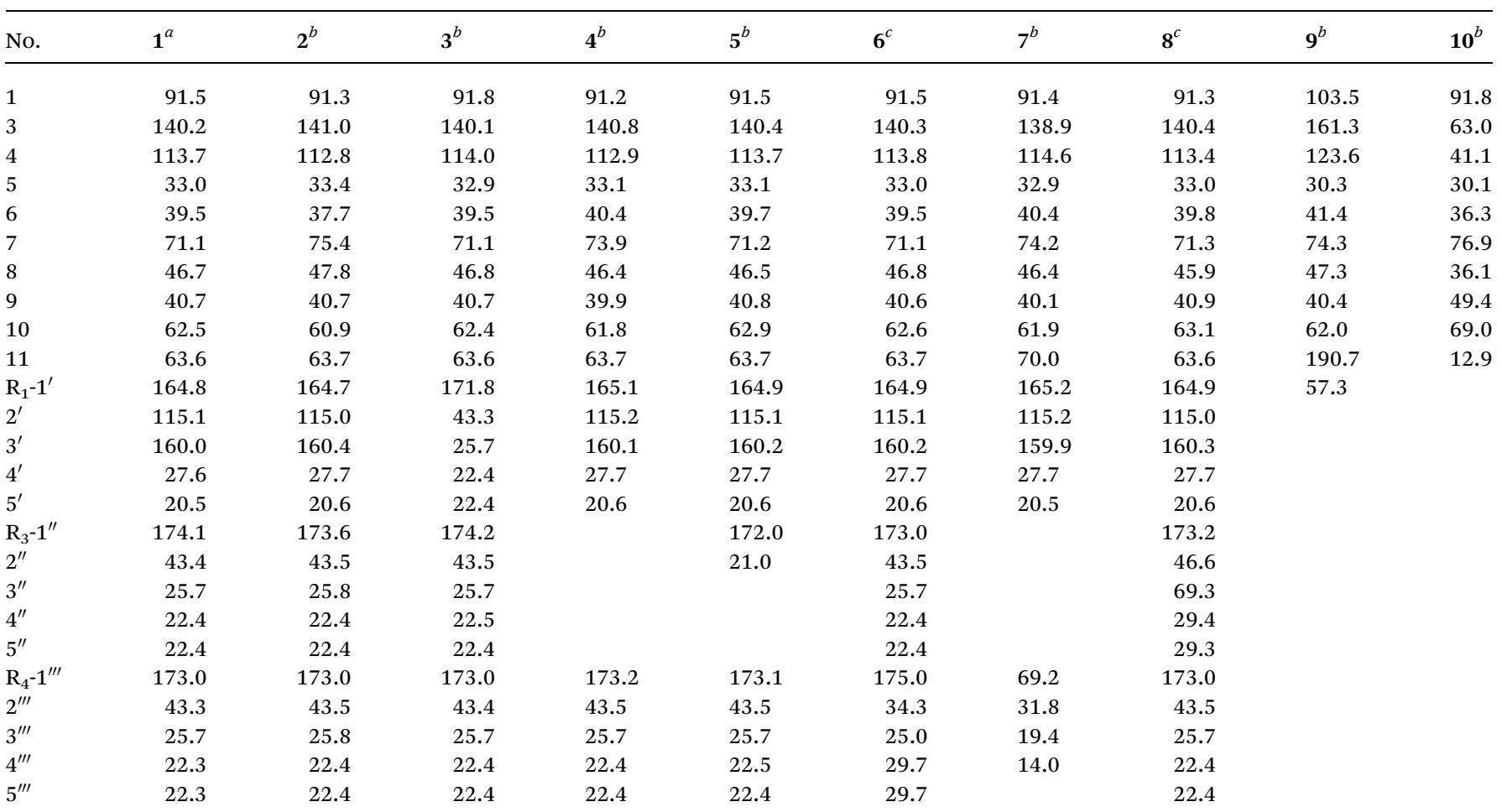

Palmitoyl of 6: $\delta_{\mathrm{C}} 29.7-29.1$ (t, C-6-13), 31.9 (t, C-14), 22.7 (t, C-15), 14.2 (q, C-16)

${ }^{a}{ }^{13} \mathrm{C}$ NMR data recorded at $100 \mathrm{MHz} .{ }^{b}{ }^{13} \mathrm{C}$ NMR data recorded at $125 \mathrm{MHz} .{ }^{c}{ }^{13} \mathrm{C}$ NMR data recorded at $150 \mathrm{MHz}$. 


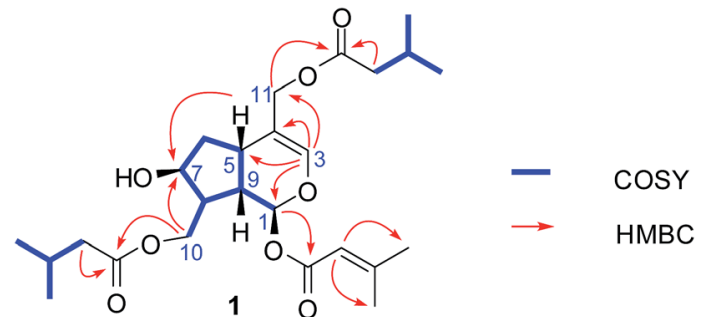

Fig. 2 Key ${ }^{1} \mathrm{H}-{ }^{1} \mathrm{H}$ COSY and $\mathrm{HMBC}$ correlations of compound 1.

491.2602), which is two mass units higher than that of 1 . The NMR data were very similar to those of compound 1 except for the appearance of an isovaleryl substituent $\left[\delta_{\mathrm{C}} 171.8 .0(\mathrm{~s}), \delta_{\mathrm{C}}\right.$ $\left.43.3(\mathrm{t}), \delta_{\mathrm{C}} 25.7(\mathrm{~d}), \delta_{\mathrm{C}} 22.4(\mathrm{q}), \delta_{\mathrm{C}} 22.4(\mathrm{q})\right]$ instead of the 3methylcrotonyl group in compound 1 . Therefore, compound 3 has three isovaleryl substituents. These three isovaleryl substituents were assigned separately at C-1, C-10, and C-11 by means of HMBC spectra. Finally, the structure of 3 was characterized as $(1 S, 5 S, 7 S, 8 S, 9 S)$-7-hydroxy-1,10,11-triisovaleroxy5,6-dihydrovaltrate hydrin, named patriscabioin $\mathrm{C}$.

Compound 4 had a molecular formula of $\mathrm{C}_{20} \mathrm{H}_{30} \mathrm{O}_{7}$ as established from HRESIMS at $m / z$ 405.1889 $[\mathrm{M}+\mathrm{Na}]^{+}$(calcd 405.1884) and ${ }^{13} \mathrm{C}$ NMR spectroscopic data. Compared with compound 1, compound $\mathbf{4}$ has one isovaleryl substituent and a 3-methylcrotonyl group according to careful analysis of the NMR data. The 3-methylcrotonyl group and isovaleryl group were attached at $\mathrm{C}-1$ and $\mathrm{C}-11$, respectively, according to correlations from $\mathrm{H}-1$ to the ester carbonyl carbon at $\delta_{\mathrm{C}} 165.1(\mathrm{~s})$ and from $\mathrm{H}-11$ to the ester carbonyl carbon at $\delta_{\mathrm{C}} 173.2(\mathrm{~s})$ in the HMBC spectra. Accordingly, the structure of compound 4 was characterized as $(1 S, 5 S, 7 S, 8 S, 9 S)-1-O$-(3-methylcrotonyl)-7,10dihydroxy-11-isovaleroxy-5,6-dihydrovaltrate hydrin, named patriscabioin D.

Compound 5 was analyzed to have a molecular formula of $\mathrm{C}_{22} \mathrm{H}_{32} \mathrm{O}_{8}$ by a combination of HRESIMS at $m / z 447.1983[\mathrm{M}+$ $\mathrm{Na}^{+}$(calcd 447.1989) and ${ }^{13} \mathrm{C}$ NMR data. Compared with the ${ }^{1} \mathrm{H}$ NMR and ${ }^{13} \mathrm{C}$ NMR spectroscopic data of compound 4 , it could be determined that $\mathbf{5}$ has a similar structure to $\mathbf{4}$ except for the appearance of an acetyl group at $\delta_{\mathrm{C}} 172.0(\mathrm{~s}), \delta_{\mathrm{C}} 21.0(\mathrm{q})$ in the ${ }^{13} \mathrm{C}$ NMR spectrum and $\delta_{\mathrm{H}} 2.09(\mathrm{~s})$ in the ${ }^{1} \mathrm{H}$ NMR spectrum. This hinted that compound 5 is an acetyl derivative of 4 at C-10 on account of the correlation from $\mathrm{H}-10$ to the acetyl carbonyl carbon at $\delta_{\mathrm{C}} \mathbf{1 7 2 . 0}(\mathrm{s})$ in the HMBC spectrum. Consequently, compound 5 was elucidated as $(1 S, 5 S, 7 S, 8 S, 9 S)-1-O-(3-m e t h y l c r o t o n y l)-7-$ dihydroxy-10-acetoxy-11-isovaleroxy-5,6-dihydrovaltrate hydrin, named patriscabioin E.

Compound 6 was formulated as $\mathrm{C}_{36} \mathrm{H}_{60} \mathrm{O}_{8}$ from HRESIMS at $m / z 659.3924[\mathrm{M}+\mathrm{K}]^{+}$(calcd 659.3920). Comparison of the NMR data showed signals similar to those of 1 except for the presence of 14 methylenes and a methyl group in the high field region, which implied that a palmitoyl group replaced the original isovaleryl substituent. This finding agrees with the molecular weight exactly. Ultimately, the structure of $\mathbf{6}$, interpreted from 2D NMR spectra, was confirmed as $(1 S, 5 S, 7 S, 8 R, 9 S)-1-O-(3-$ methylcrotonyl)-7-hydroxy-10-isovaleroxy-11-palmitoyl-oxy-5,6dihydrovaltrate hydrin, named patriscabioin $\mathrm{F}$.
The molecular formula of compound 7 was inferred to be $\mathrm{C}_{19} \mathrm{H}_{30} \mathrm{O}_{6}$ by HRESIMS at $\mathrm{m} / z$ 377.1934 $[\mathrm{M}+\mathrm{Na}]^{+}$(calcd 377.1935). The ${ }^{1} \mathrm{H}$ and ${ }^{13} \mathrm{C}$ NMR data revealed that compound 7 is an analogue of 4; the only difference is the $\mathrm{C}-11$ substituent group, which was defined as an $n$-butoxy unit by the ${ }^{1} \mathrm{H}$ and ${ }^{13} \mathrm{C}$ NMR data. By analysis of 2D NMR data, compound 7 was further identified as $(1 S, 5 S, 7 S, 8 S, 9 S)$-1-O-(3-methylcrotonyl)-7-hydroxy10-isovaleroxy-11- $n$-butoxy-5,6-dihydrovaltrate hydrin, named patriscabioin $\mathrm{G}$.

Compound 8 possessed a molecular formula of $\mathrm{C}_{25} \mathrm{H}_{38} \mathrm{O}_{9}$, deduced from HRESIMS at $m / z$ 505.2407 $[\mathrm{M}+\mathrm{Na}]^{+}$(calcd 505.2408). The ${ }^{1} \mathrm{H}$ and ${ }^{13} \mathrm{C}$ NMR spectroscopic data were almost identical to those of 1 ; however, a methine $\left(\delta_{\mathrm{C}} 25.7\right)$ was absent and an oxygenated tetrahedral carbon $\left(\delta_{\mathrm{C}} 69.3\right)$ was present along with two methyl groups downfield at $\delta_{\mathrm{C}} 29.3(\mathrm{q}), \delta_{\mathrm{H}} 1.31(\mathrm{~s}) ; \delta_{\mathrm{C}}$ $29.4(\mathrm{q}), \delta_{\mathrm{H}} 1.25(\mathrm{~s})$. These spectroscopic differences suggested the presence of a 3-hydroxylisovaleryl group in 8 at $\mathrm{C}-10$, in accordance with the HMBC correlation from $\mathrm{H}-10$ to the carbonyl $\left(\delta_{\mathrm{C}} 173.2\right)$ of the 3-hydroxylisovaleryl group. After assignment of the $1 \mathrm{D}$ and $2 \mathrm{D}$ NMR data of 8 , the structure was characterized as $(1 S, 5 S, 7 S, 8 S, 9 S)$-1-O-(3-methylcrotonyl)-7-hydroxy10-(3-hydroxylisovaleroxy)-11-isovaleroxy-5,6-dihydrovaltrate hydrin, named patriscabioin $\mathrm{H}$.

Compound 9 was assigned a molecular formula of $\mathrm{C}_{11} \mathrm{H}_{16} \mathrm{O}_{5}$ from HRESIMS at $m / z 251.0885[\mathrm{M}+\mathrm{Na}]^{+}$(calcd 251.0890) and ${ }^{13} \mathrm{C}$ NMR data. In addition to a methoxy group at $\delta_{\mathrm{C}} 57.3$, we observed a typical acetal group at $\delta_{\mathrm{C}} 103.5(\mathrm{~d}), \delta_{\mathrm{H}} 4.65(\mathrm{~d}, J=6.0$ $\mathrm{Hz}$ ); a conjugated aldehyde group at $\delta_{\mathrm{C}} 190.7(\mathrm{~d}), \delta_{\mathrm{H}} 9.29(\mathrm{~s})$; and an adjacent double bond at $\delta_{\mathrm{C}} 161.3(\mathrm{~d}), \delta_{\mathrm{C}} 123.6(\mathrm{~s})$. All these spectroscopic features are close to those of the known compound 1-O-methyl cachinol, ${ }^{16}$ except for the absence of a methyl and the presence of an oxymethylene, suggesting that the methyl group at $\mathrm{C}-10$ was oxygenated to an O-methylene group. After further confirmation of the structure by ${ }^{1} \mathrm{H}-{ }^{1} \mathrm{H}$ COSY, HSQC, HMBC, and ROESY data, it was assigned as $(1 R, 5 S, 7 S, 8 S, 9 S)$-1-methoxy-7,10-dihydroxy-11-aldehyde-5,6dihydrovaltrate hydrin, named patriscabioin $\mathrm{I}$.

Compound 10 was found to have a molecular formula of $\mathrm{C}_{10} \mathrm{H}_{16} \mathrm{O}_{3}$ by HRESIMS at $m / z$ 207.0991 $[\mathrm{M}+\mathrm{Na}]^{+}$(calcd 207.0992), with 3 degrees of unsaturation. The NMR spectra of 10 revealed a hemiketal methine at $\delta_{\mathrm{C}} 91.8(\mathrm{~d}, \mathrm{C}-1)$ and $\delta_{\mathrm{H}} 4.80$ $(\mathrm{d}, J=2.0 \mathrm{~Hz})$; two oxygenated methylenes at $\delta_{\mathrm{C}} 63.0(\mathrm{t})$ and $\delta_{\mathrm{C}}$ $69.0(\mathrm{t})$; an oxymethine at $\delta_{\mathrm{C}} 76.9(\mathrm{t})$; and a methyl at $\delta_{\mathrm{C}} 12.9(\mathrm{q})$ and $\delta_{\mathrm{H}} 1.05(\mathrm{~d}, J=6.9 \mathrm{~Hz})$. These data suggested that the compound was a 7-hydroxy-3,4,5,6-tetrahydrovaltrate hydrin in which a methyl was changed to an oxymethylene. However, the cyclization of $\mathrm{C}-10$ with $\mathrm{OH}-1$ was confirmed by the correlations from $\mathrm{H}-1$ to $\mathrm{C}-3\left(\delta_{\mathrm{C}} 63.0, \mathrm{t}\right)$ and $\mathrm{C}-10\left(\delta_{\mathrm{C}} 69.0, \mathrm{t}\right)$ in the HMBC spectrum. The $\beta$-configurations of $\mathrm{H}-1, \mathrm{Me}-11$, and $\mathrm{H}-8$ and the $\alpha$-configuration of $\mathrm{H}-7$ were determined by the correlations of $\mathrm{H}-1 / \mathrm{H}-9$, Me-11/H-1, H-8/H-9, and $\mathrm{H}-7 / \mathrm{H}-4$ in the ROESY spectrum. Hence, the structure of compound $\mathbf{1 0}$ was established as $\quad(1 R, 4 R, 5 R, 7 S, 8 R, 9 S)$-1,10-epoxy-7-hydroxy-3,4,5,6tetrahydrovaltrate hydrin, named patriscabioin $\mathrm{J}$.

Compounds 11 and 12 possessed the same molecular formula, $\mathrm{C}_{30} \mathrm{H}_{40} \mathrm{O}_{9}$, according to HRESIMS, with 11 degrees of unsaturation. The IR spectrum of compound $\mathbf{1 1}$ showed 
absorption bands of hydroxy groups $\left(3435 \mathrm{~cm}^{-1}\right)$, a conjugated group consisting of an aldehyde function $\left(1731 \mathrm{~cm}^{-1}\right)$ and a double bond $\left(1644 \mathrm{~cm}^{-1}\right)$, and two ethers (1126 and 1089 $\mathrm{cm}^{-1}$ ). Furthermore, compound 12 showed similar absorptions to $\mathbf{1 1}$ in its IR spectrum. Careful analysis of the NMR data indicated that two compounds exhibited similar NMR spectroscopic features except for their data in the low magnetic field. Furthermore, their NMR spectroscopic data showed two distinct regions, indicating a dimer of two iridoid units. One was easily assigned to compound 4; another was identified as 8,9-didehydro-7-hydroxydolichodial, ${ }^{17}$ except for the absence of an aldehyde group and the presence of an acetal. This suggested that two units were linked through the aldehyde group. Also, the difference between compounds $\mathbf{1 1}$ and $\mathbf{1 2}$ was the position of the aldehyde group of 8,9-didehydro-7-hydroxydolichodial. In 11, this group was linked at $\mathrm{C}-\mathbf{1}^{\prime}$ based on the correlations of $\mathrm{H}$ $1^{\prime} / \mathrm{C}-10, \mathrm{C}-7$ in the HMBC spectrum, while compound 12 was placed at $\mathrm{C}-3^{\prime}$ by detailed analysis of the HMBC correlations from $\mathrm{H}-3^{\prime} / \mathrm{C}-10$, C-7 (Fig. 5). In addition, detailed analysis of the ROESY data showed that the configurations of the two iridoid units are the same as in compound $\mathbf{4}$ and 8,9-didehydro-7hydroxydolichodial. The $\alpha$-configuration of $\mathrm{H}-\mathbf{1}^{\prime}$ in $\mathbf{1 1}$ and the $\alpha$-configuration of $\mathrm{H}-3^{\prime}$ in $\mathbf{1 2}$ were assigned by the correlations of $\mathrm{H}-1^{\prime} / \mathrm{H}-7$ and $\mathrm{H}-3^{\prime} / \mathrm{H}-7$ in the ROESY experiments, respectively (Fig. 6). The good agreement between the experimental and calculated ECD spectra of compounds 11 and 12 (Fig. 4) further proved the $\alpha$-configurations of $\mathrm{H}-1^{\prime}$ of compound 11 and $\mathrm{H}-3^{\prime}$ of compound 12. Hence, the structures of patriscabiobisin A (11) and patriscabiobisin B (12) were characterized as shown.

Compound 13 was isolated as a light yellow oil with a molecular formula of $\mathrm{C}_{21} \mathrm{H}_{28} \mathrm{O}_{8}$ based on HRESIMS at $\mathrm{m} / z$ 447.1418 $[\mathrm{M}+\mathrm{K}]^{+}$(calcd 447.1416). Its UV spectrum displayed absorptions of conjugated aldehyde and olefinic groups at $247 \mathrm{~nm}$ and $202 \mathrm{~nm}$. The IR spectrum showed broad absorptions for a hydroxy group $\left(3431 \mathrm{~cm}^{-1}\right)$, an $\alpha, \beta$-unsaturated aldehyde group $\left(1713,1662 \mathrm{~cm}^{-1}\right)$, and an ether $\left(1076 \mathrm{~cm}^{-1}\right)$. Detailed analysis of the ${ }^{1} \mathrm{H}$ and ${ }^{13} \mathrm{C}$ NMR spectroscopic data of 13 revealed that it exhibited two sets of $\mathrm{C}_{10}$-iridoid signals, of which one unit was determined to be patriscabioin I (9) and the other was judged to be jatamanin D. ${ }^{\mathbf{1 1}}$ The difference was that the two sets of data shifted to a lower field $\left[\delta_{\mathrm{C}} 62.0(\mathrm{t}) \rightarrow \delta_{\mathrm{C}} 68.7\right.$ $\left.(\mathrm{t}, \mathrm{C}-10) ; \delta_{\mathrm{C}} 91.1(\mathrm{~d}) \rightarrow \delta_{\mathrm{C}} 97.5\left(\mathrm{~d}, \mathrm{C}-1^{\prime}\right)\right]$. This suggested that those two units were connected through $\mathrm{C}-10-\mathrm{O}-\mathrm{C}-\mathbf{1}^{\prime}$, which was further verified by correlations from $\mathrm{H}-1^{\prime}\left(\delta_{\mathrm{H}} 5.15\right)$ to $\mathrm{C}-10$

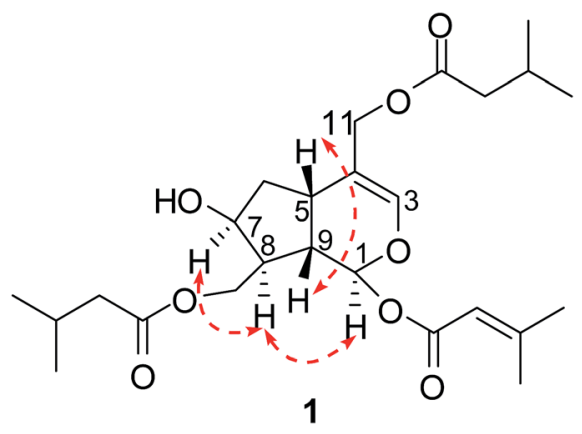

Fig. 3 Key ROESY correlations of compound 1.
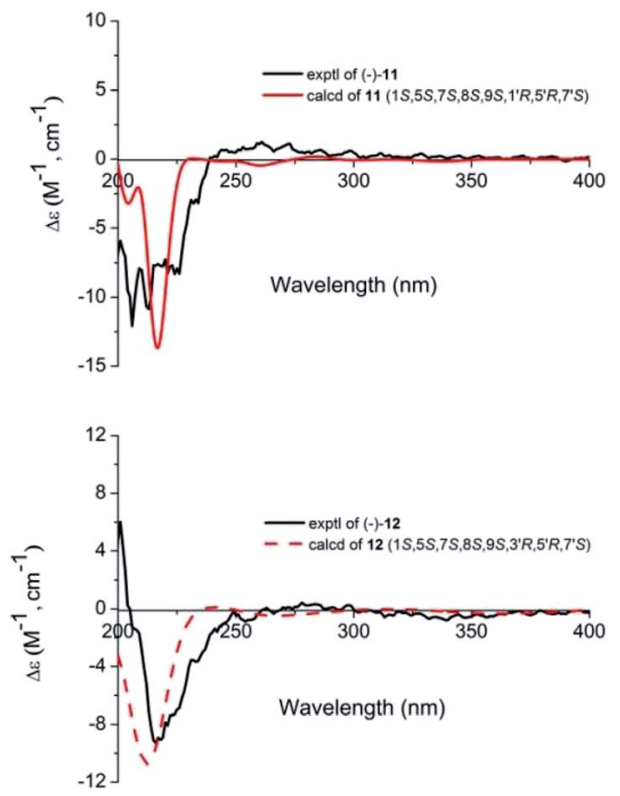

Fig. 4 Calculated and experimental ECD spectra of compounds 11 and 12 at the TDDFT/B3LYP/6-31G(d) level.

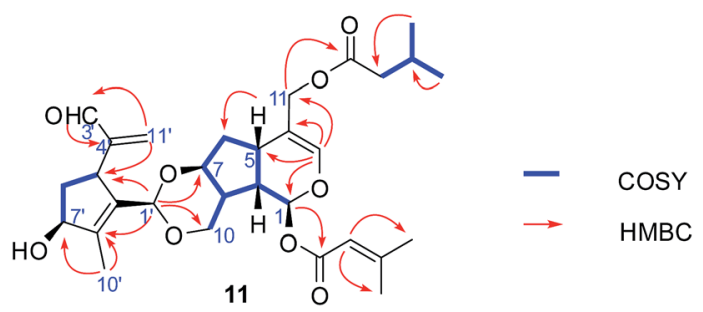

Fig. 5 Key ${ }^{1} \mathrm{H}-{ }^{1} \mathrm{H}$ COSY and $\mathrm{HMBC}$ correlations of compound 11.

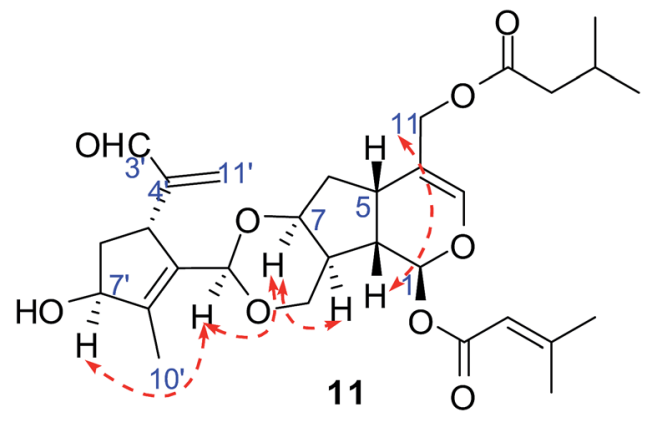

Fig. 6 Key ROESY correlations of compound 11.

$\left(\delta_{\mathrm{C}}\right.$ 68.7) in the HMBC spectrum. The configurations of the two iridoid units were the same as in compound 9 and jatamanin D. Therefore, patriscabiobisin C (13) was characterized as shown.

Compounds 1 to 8 are a series of 5,6-dihydrovaltrate hydrins with substituent groups unique to the Valerianaceae family such as isovaleryl, 3-methylcrotonyl, 3-hydroxylisovaleryl, and palmitoyl groups. Compound 9 contains a conjugated aldehyde group with a double bond, and compound 10 contains a 6/5/5 
Table $4{ }^{1} \mathrm{H}$ NMR $(600 \mathrm{MHz})$ and ${ }^{13} \mathrm{C}$ NMR (150 MHz) data of compounds 11 and $12\left(\mathrm{CDCl}_{3}\right)$ and $13\left(\mathrm{CD}{ }_{3} \mathrm{OD}\right)(\delta$ in ppm, $\mathrm{J}$ in $\mathrm{Hz})$

\begin{tabular}{|c|c|c|c|c|c|c|}
\hline \multirow[b]{2}{*}{ No. } & \multicolumn{2}{|l|}{11} & \multicolumn{2}{|l|}{12} & \multicolumn{2}{|l|}{13} \\
\hline & $\delta_{\mathrm{H}}$ & $\delta_{\mathrm{C}}$ & $\delta_{\mathrm{H}}$ & $\delta_{\mathrm{C}}$ & $\delta_{\mathrm{H}}$ & $\delta_{\mathrm{C}}$ \\
\hline 1 & $5.89(\mathrm{~d}, 5.2)$ & 91.4 & $5.94(\mathrm{~d}, 4.9)$ & 91.1 & $5.06(\mathrm{~d}, 3.8)$ & 104.2 \\
\hline 3 & $6.36(\mathrm{~s})$ & 139.9 & $6.36(\mathrm{~s})$ & 139.8 & $7.39(\mathrm{~s})$ & 163.7 \\
\hline 4 & & 114.3 & & 114.3 & & 126.2 \\
\hline 5 & $2.93(\mathrm{q}, 8.2)$ & 33.2 & $3.04(\mathrm{q}, 8.0)$ & 33.1 & $3.02(\mathrm{q}, 7.6)$ & 30.3 \\
\hline $6 a$ & $2.06(\mathrm{~m})$ & 38.3 & $2.17(\mathrm{~m})$ & 38.2 & $2.17(\mathrm{~m})$ & 41.4 \\
\hline $6 b$ & $1.58(\mathrm{~m})$ & 77.8 & $1.68(\mathrm{~m})$ & 78.0 & $1.74(\mathrm{~m})$ & 73.5 \\
\hline 7 & $4.15(t, 3.7)$ & & $4.23(t, 3.8)$ & & $4.21(\mathrm{~m})$ & \\
\hline 8 & $1.65(\mathrm{~m})$ & 40.7 & $1.70(\mathrm{~m})$ & 40.6 & $2.03(\mathrm{~m})$ & 47.0 \\
\hline 9 & $2.58(\mathrm{~m})$ & 39.9 & $2.67(\mathrm{~m})$ & 39.9 & $2.34(\mathrm{~m})$ & 44.5 \\
\hline $10 \mathrm{a}$ & $4.07(\mathrm{~d}, 12.1)$ & 66.1 & $4.15(\mathrm{~d}, 12.1)$ & 66.2 & $3.91(\mathrm{dd}, 9.4,7.6)$ & 68.7 \\
\hline $10 \mathrm{~b}$ & $3.98(\mathrm{dd}, 11.9,2.8)$ & & $4.06(\mathrm{dd}, 12.1,3.1)$ & & $3.74(\mathrm{dd}, 9.4,6.3)$ & \\
\hline $11 \mathrm{a}$ & $4.55(\mathrm{~d}, 12.3)$ & 63.7 & $4.59(\mathrm{~d}, 12.3)$ & 63.7 & $9.21(\mathrm{~s})$ & 193.5 \\
\hline $11 b$ & $4.41(\mathrm{~d}, 12.3)$ & & $4.41(\mathrm{~d}, 12.3)$ & & & \\
\hline OMe & & & & & $3.53(\mathrm{~s})$ & 57.2 \\
\hline Cr-1 & & 165.0 & & 165.0 & & \\
\hline 2 & $5.70(\mathrm{~s})$ & 115.2 & $5.69(\mathrm{~s})$ & 115.2 & & \\
\hline 3 & & 160.1 & & 160.0 & & \\
\hline 4 & $1.94(\mathrm{~s})$ & 27.7 & $1.94(\mathrm{~s})$ & 27.7 & & \\
\hline 5 & $2.20(\mathrm{~s})$ & 20.6 & $2.20(\mathrm{~s})$ & 20.6 & & \\
\hline Iv-1 & & 173.0 & & 173.1 & & \\
\hline 2 & $2.19(\mathrm{~d}, 5.9)$ & 43.5 & $2.19(\mathrm{~d}, 4.4)$ & 43.5 & & \\
\hline 3 & $2.07(\mathrm{~m})$ & 25.7 & $2.10(\mathrm{~m})$ & 25.8 & & \\
\hline 4 & $0.96(\mathrm{~d}, 6.7)$ & 22.5 & $0.96(\mathrm{~d}, 6.6)$ & 22.4 & & \\
\hline 5 & $0.96(\mathrm{~d}, 6.7)$ & 22.4 & $0.96(\mathrm{~d}, 6.6)$ & 22.4 & & \\
\hline $1^{\prime}$ & $5.11(\mathrm{~s})$ & 97.2 & $9.99(\mathrm{~s})$ & 188.6 & $5.15(\mathrm{~d}, 3.0)$ & 97.5 \\
\hline $3^{\prime}$ & $9.52(\mathrm{~s})$ & 194.0 & $4.95(\mathrm{~s})$ & 101.6 & $5.04(\mathrm{~s})$ & 95.0 \\
\hline $4^{\prime}$ & & 152.8 & & 147.3 & & 151.7 \\
\hline $5^{\prime}$ & $3.98(\mathrm{~m})$ & 41.8 & $3.84(\mathrm{~m})$ & 42.5 & $3.12(t, 5.9)$ & 43.6 \\
\hline $6 a^{\prime}$ & $2.09(\mathrm{~m})$ & 41.0 & $2.43(\mathrm{~m})$ & 40.7 & $2.09(\mathrm{~m})$ & \\
\hline $6 b^{\prime}$ & $1.96(\mathrm{~m})$ & 41.0 & $1.90(\mathrm{~m})$ & 40.7 & $1.87(\mathrm{~m})$ & \\
\hline $7^{\prime}$ & 4.74 (br s) & 80.1 & 4.88 (br s) & 80.0 & $3.81(\mathrm{dd}, 7.6,3.1)$ & 79.9 \\
\hline $8^{\prime}$ & & 143.2 & & 161.5 & & 83.6 \\
\hline $9^{\prime}$ & & 135.2 & & 139.1 & $2.34(\mathrm{~m})$ & 44.5 \\
\hline $10^{\prime}$ & $1.88(\mathrm{~s})$ & 11.7 & $2.23(\mathrm{~s})$ & 11.5 & $1.38(\mathrm{~s})$ & 19.4 \\
\hline $11 a^{\prime}$ & $6.18(\mathrm{~s})$ & 133.2 & $5.18(\mathrm{~s})$ & 112.8 & $4.92(\mathrm{~s})$ & 107.4 \\
\hline $11 b^{\prime}$ & $5.90(\mathrm{~s})$ & & $4.76(\mathrm{~s})$ & & $4.82(\mathrm{~s})$ & \\
\hline
\end{tabular}

Table 5 Acetylcholinesterase (AChE) inhibitory activities of compounds 1 to 13

\begin{tabular}{|c|c|c|c|c|c|c|c|}
\hline Compound & 1 & 2 & 3 & 4 & 5 & 6 & 7 \\
\hline Inhibition (\%) & 68.53 & 29.73 & 75.23 & -5.30 & 7.19 & 40.49 & -42.42 \\
\hline $\mathrm{SD}$ & 0.90 & 2.87 & 0.42 & 2.47 & 4.45 & 2.05 & 1.81 \\
\hline Inhibitiory activity & +++ & ++ & +++ & - & - & ++ & - \\
\hline Compound & 8 & 9 & 10 & 11 & 12 & 13 & $\mathrm{TA}$ \\
\hline Inhibition (\%) & 17.78 & 46.97 & -14.54 & 36.03 & 21.91 & 37.87 & 51.01 \\
\hline SD & 2.58 & 4.43 & 2.76 & 4.31 & 2.79 & 6.33 & 1.96 \\
\hline
\end{tabular}

ring system. Furthermore, compounds $\mathbf{1 1}$ to $\mathbf{1 3}$ are the first reported bis-iridoids; among these, compounds $\mathbf{1 1}$ and $\mathbf{1 2}$ are connected with a 1,3-dioxane group between two units, while compound 13 is linked by an ether bond.

\subsection{Biological evaluation}

P. scabiosaefolia has been used for sedation, ${ }^{7}$ in which acetylcholine esterase inhibitors may be responsible for the sedation effects $;^{18}$ therefore, the inhibitory activities on AChE of all the new compounds were tested. The screening results (Table 5) showed that at concentrations of $50 \mu \mathrm{M}$, compounds 1 and 3 inhibited acetylcholine esterase activity over $60 \%$, and compounds 2, 6, 9, and 11 to 13 inhibited acetylcholine esterase activity from $20 \%$ to $50 \%$; however, compounds $4,5,7,8$, and 10 basically had no inhibitory activities. Then, the $\mathrm{IC}_{50}$ values of compounds $\mathbf{1}$ and $\mathbf{3}$ were examined. Compared with the 
reference compound tacrine $\left(\mathrm{IC}_{50}=0.4 \mu \mathrm{M}\right)$, these compounds showed moderate inhibitory activities on $\mathrm{AChE}$, with $\mathrm{IC}_{50}$ values of 37.6 and $10.5 \mu \mathrm{M}$, respectively. These results suggested that the presence of $7 \beta-\mathrm{OH}$ and $10-\mathrm{Iv}$ may be essential to the inhibitory activities of the compounds on acetylcholine esterase. Of course, the structure-activity relationships of the inhibitory activities of these compounds on acetylcholine esterase remain to be further explored.

The final concentration of tacrine (TA) was $0.333 \mu \mathrm{M}$, and the final concentrations of the compounds were $50 \mu \mathrm{M}$. "-": Inhibition $(\%)<10 \%$; "+": Inhibition (\%) from $10 \%$ to $20 \%$; “++": Inhibition (\%) from $20 \%$ to $60 \%$; “+++": Inhibition (\%) $>60 \%$.

Considering the cytotoxicity of iridoids, ${ }^{14}$ all new compounds were evaluated for their cytotoxicities in vitro against four human cancer cell lines (HL-60, SMMC-7721, MCF-7, and SW-480) by MTT assay, ${ }^{19}$ using cisplatin (DDP) and paclitaxel as positive controls (Table 6). As a result, compound 1 showed moderate cytotoxic activity, with $\mathrm{IC}_{50}$ values of 1.4, 7.2, and 7.1 $\mu \mathrm{M}$ against HL-60, SMMC-7721, and SW480, respectively, which is comparable to cisplatin (DDP). Meanwhile, compound 5 showed cytotoxicity against HL-60, with an $\mathrm{IC}_{50}$ value of $1.2 \mu \mathrm{M}$. Consequently, $7 \beta-\mathrm{OH}$ and the substituent at C-10 may be responsible for the cytotoxic activity of these iridoids. Furthermore, the Cr-group may improve the activity. Moreover, in order to know their selectivity, compounds 1-3, 5 and $\mathbf{1 1}$ were tested for their cytotoxicities towards human normal epithelium cells (BEAS-2B). The results (Table 7) showed that human normal epithelium cells showed viable, even the concentration of these compounds was increased to $40 \mu \mathrm{M}$ (Table 7).

Table $6 \quad I C_{50}$ values $(\mu \mathrm{M})$ of compounds 1 to 3,5 and 11 for human tumor cell lines ${ }^{a}$

\begin{tabular}{lllll}
\hline Compound & HL-60 & SMMC-7721 & MCF-7 & SW-480 \\
\hline $\mathbf{1}$ & $1.4 \pm 0.02$ & $7.2 \pm 0.29$ & $27.6 \pm 1.68$ & $7.1 \pm 0.35$ \\
$\mathbf{2}$ & - & - & - & $24.3 \pm 2.39$ \\
$\mathbf{3}$ & $9.9 \pm 1.52$ & $13.8 \pm 0.17$ & $17.8 \pm 0.54$ & $10.0 \pm 0.28$ \\
$\mathbf{5}$ & $1.2 \pm 0.05$ & $7.1 \pm 0.38$ & - & $18.2 \pm 0.19$ \\
$\mathbf{1 1}$ & $17.9 \pm 0.73$ & $19.7 \pm 0.62$ & $23.9 \pm 1.85$ & $17.6 \pm 0.26$ \\
Cisplatin & $2.8 \pm 0.12$ & $5.9 \pm 0.17$ & $20.4 \pm 1.07$ & $7.6 \pm 0.54$ \\
Paclitaxel & $<0.008$ & $<0.008$ & $<0.008$ & $<0.008$
\end{tabular}

a “_": inactive for cell lines. Cisplatin and paclitaxel: positive controls.

Table 7 Cell viability of compounds 1 to 3,5 and 11 for human normal epithelium cells (BEAS-2B)

\begin{tabular}{llllllll}
\hline \multirow{2}{*}{$\begin{array}{l}\text { Concentration } \\
(\mu \mathrm{M})\end{array}$} & \multicolumn{6}{l}{ Cell viability $(\%)$} \\
\cline { 2 - 8 } & $\mathbf{1}$ & $\mathbf{2}$ & $\mathbf{3}$ & $\mathbf{5}$ & $\mathbf{1 1}$ & Cisplatin & Paclitaxel \\
\hline 0.064 & 95.9 & 96.3 & 97.9 & 97.9 & 97.7 & 93.0 & 93.1 \\
0.32 & 98.8 & 98.0 & 99.1 & 98.1 & 97.6 & 94.2 & 93.5 \\
1.6 & 98.9 & 98.8 & 97.4 & 97.1 & 94.9 & 92.1 & 89.1 \\
8 & 99.1 & 99.5 & 96.9 & 97.6 & 95.8 & 82.9 & 83.3 \\
40 & 97.5 & 97.2 & 92.9 & 94.4 & 86.9 & 61.3 & 53.9
\end{tabular}

\section{Experimental section}

\subsection{General procedure}

Optical rotations were obtained on a JASCO P-1020 digital polarimeter (Horiba, Tokyo, Japan). UV spectra were measured using a Shimadzu UV-2401 PC spectrophotometer (Shimadzu, Kyoto, Japan). IR spectra were obtained on a Bruker Tensor 27 infrared spectrophotometer (Bruker Optics GmbH, Ettlingen, Germany) with $\mathrm{KBr}$ pellets. Mass spectra were performed on an API QSTAR time-of-flight spectrometer (MDS Sciqaszex, Concord, Ontario, Canada) and an LCMS-IT-TOF (Shimadzu, Kyoto, Japan) spectrometer. NMR spectra were recorded on Bruker AM-400, DRX-500 and Av III-600 instruments with TMS as the internal standard (Bruker, Bremerhaven, Germany). The chemical shifts were given in $\delta$ (ppm) with reference to the solvent signal. Column chromatography was performed on silica gel (200-300 and 300-400 mesh, Qingdao Marine Chemical Inc., Qingdao, China), Lichroprep Rp-18 gel (40 to $63 \mu \mathrm{m}$, Merck, Darmstadt, Germany), MCI gel CHP-20P (75 to $150 \mu \mathrm{m}$, Mitsubishi Chemical Corp., Tokyo, Japan), Sephadex LH-20 (20 to $150 \mu \mathrm{m}$, Amersham Biosciences, Uppsala, Sweden), and YMC*GEL ODS-A-HG (50 $\mu \mathrm{m}$, YMC Co. Ltd. Japan). The fractions were monitored by TLC, and the spots were visualized by UV light and sprayed with $10 \% \mathrm{H}_{2} \mathrm{SO}_{4}$ in EtOH, followed by heating.

\subsection{Plant material}

Whole plants of P. scabiosaefolia were collected in October 2001 from Shucheng County, Anhui Province, People's Republic of China; the plants were stored in a cool and dry place at room temperature. The material was identified by Prof. Shou-Jin Liu at the Anhui University of Chinese Medicine, and a voucher specimen (Wan1295) was deposited at the Anhui University of Chinese Medicine.

P. scabiosaefolia plants are abundant in local resources, and collection was permitted. Also, we ensured that the local population of $P$. scabiosaefolia was not destroyed by collecting specimens at different locations.

\subsection{Extraction and isolation}

The air-dried and powdered whole plants $(29 \mathrm{~kg})$ of $P$. scabiosaefolia were extracted with $95 \%$ ethanol $(3 \times 75 \mathrm{~L})$ under room temperature and concentrated under reduced pressure. Then, the residue $(3 \mathrm{~kg}$ ) was dissolved in water and partitioned successively with EtOAc to yield EtOAc extract $(0.85 \mathrm{~kg})$ after concentration. The EtOAc extract was subjected to silica gel column chromatography eluted with a gradient of petroleum ether-ethyl acetate $(20: 1 \rightarrow 0: 1, \mathrm{v} / \mathrm{v})$ to obtain six fractions ( 1 to 6$)$ by TLC plate analysis. Fraction 2 (64 g) was separated by silica gel column chromatography eluted with a gradient of petroleum ether-acetone $(5: 1 \rightarrow 1: 1, \mathrm{v} / \mathrm{v})$ to afford 4 subfractions (Fr.2-1 to Fr.2-4). Fr.2-1 (5.9 g) was separated by Sephadex LH-20 column chromatography $\left(\mathrm{MeOH}-\mathrm{H}_{2} \mathrm{O}, 90: 10\right.$, $\mathrm{v} / \mathrm{v}$ ), and Rp-18 column chromatography $\left(\mathrm{MeOH}-\mathrm{H}_{2} \mathrm{O}, 50: 50\right.$ $\rightarrow 100: 0, \mathrm{v} / \mathrm{v}$ ) and was further purified by semi-prep. HPLC $\left(\mathrm{MeOH}-\mathrm{H}_{2} \mathrm{O}, 75: 25, \mathrm{v} / \mathrm{v}\right)$ to afford $1\left(14.1 \mathrm{mg}, t_{\mathrm{R}}=30.9 \mathrm{~min}\right)$ 
and $16\left(15.0 \mathrm{mg}, t_{\mathrm{R}}=23.2 \mathrm{~min}\right)$. Fr.2-2 (1.6 g) was chromatographed on a Sephadex LH-20 column $\left(\mathrm{MeOH}-\mathrm{H}_{2} \mathrm{O}, 90: 10, \mathrm{v} / \mathrm{v}\right)$ and on a silica gel column with petroleum ether-ethyl acetate $(10: 1, \mathrm{v} / \mathrm{v})$ to acquire $3(5.7 \mathrm{mg})$. Fraction $3(62 \mathrm{~g})$ was separated by silica gel column chromatography eluted with a gradient of petroleum ether-acetone $(5: 1 \rightarrow 1: 1, \mathrm{v} / \mathrm{v})$ to afford 6 subfractions (Fr.3-1 to Fr.3-6). Fr.3-1 (507.2 mg) was separated by Sephadex LH-20 column chromatography $\left(\mathrm{MeOH}-\mathrm{H}_{2} \mathrm{O}, 90: 10\right.$, $\mathrm{v} / \mathrm{v}$ ) and silica gel column chromatography eluted with petroleum ether-ethyl acetate $(6: 1, \mathrm{v} / \mathrm{v})$ and purified by semi-prep. HPLC $\left(\mathrm{MeOH}-\mathrm{H}_{2} \mathrm{O}, 95: 5, \mathrm{v} / \mathrm{v}\right)$ to afford $6\left(2.2 \mathrm{mg}, t_{\mathrm{R}}=29.8\right.$ min). Fr.3-5 (10 g) and Fr.3-6 (5.7 g) were separated by Rp-18 column chromatography $\left(\mathrm{MeOH}-\mathrm{H}_{2} \mathrm{O}, 50: 50 \rightarrow 100: 0, \mathrm{v} / \mathrm{v}\right)$, Sephadex LH-20 column chromatography $\left(\mathrm{MeOH}-\mathrm{H}_{2} \mathrm{O}\right.$, $90: 10, \mathrm{v} / \mathrm{v})$, and silica gel column chromatography eluted with petroleum ether-ethyl acetate $(5: 1, \mathrm{v} / \mathrm{v})$ to obtain $2(1.8 \mathrm{mg}), 15$ $(2.0 \mathrm{mg})$, and $17(23.0 \mathrm{mg})$. Fraction $4(69 \mathrm{~g})$ was separated by Rp-18 column chromatography $\left(\mathrm{MeOH}-\mathrm{H}_{2} \mathrm{O}, 50: 50 \rightarrow 100: 0\right.$, v/v) to afford 7 subfractions (Fr.4-1 to Fr.4-6). Fr.4-1 (2.2 g) and Fr.4-2 (1.0 g) were all separated by Sephadex LH-20 column chromatography $\left(\mathrm{MeOH}-\mathrm{H}_{2} \mathrm{O}, 90: 10, \mathrm{v} / \mathrm{v}\right)$ and silica gel column chromatography $\left(\mathrm{CHCl}_{3}-\mathrm{MeOH}, 30: 1, \mathrm{v} / \mathrm{v}\right)$ to obtain 10 (6.0 mg), 4 (8.0 mg), and 7 (3.5 mg). Fr.4-6 (1.7 g) was separated by successive silica gel column chromatography $\left(\mathrm{CHCl}_{3}-\mathrm{MeOH}\right.$, $30: 1, \mathrm{v} / \mathrm{v}$ and petroleum ether-ethyl acetate $1: 1, \mathrm{v} / \mathrm{v}$ ) to yield 5 (9.0 mg), 14 (20.0 mg), and 18 (5.0 mg); meanwhile, purification by semi-prep. HPLC $\left(\mathrm{MeOH}-\mathrm{H}_{2} \mathrm{O}, 72: 28, \mathrm{v} / \mathrm{v}\right)$ afforded 8 $\left(2.20 \mathrm{mg}, t_{\mathrm{R}}=29.8 \mathrm{~min}\right)$. Fraction $6(5.2 \mathrm{~g})$ was isolated by the same method as Fr.4-6, and compounds 9 (3.0 mg), 19 (6.0 mg) and $20(22.0 \mathrm{mg})$ were obtianed; in addition, compounds $\mathbf{1 1}$ $\left(1.0 \mathrm{mg}, t_{\mathrm{R}}=10.0 \mathrm{~min}\right)$ and $12\left(1.0 \mathrm{mg}, t_{\mathrm{R}}=12.5 \mathrm{~min}\right)$ were purified by semi-prep. HPLC $\left(\mathrm{MeOH}-\mathrm{H}_{2} \mathrm{O}, 50: 50, \mathrm{v} / \mathrm{v}\right)$, and compound $13\left(1.0 \mathrm{mg}, t_{\mathrm{R}}=19.8 \mathrm{~min}\right)$ was obtained by semiprep. HPLC $\left(\mathrm{MeOH}-\mathrm{H}_{2} \mathrm{O}, 35: 65, \mathrm{v} / \mathrm{v}\right)$.

\subsection{Spectral data of the new compounds}

3.4.1 Patriscabioin A (1). Light yellow oil. $[\alpha]_{\mathrm{D}}^{23}-42.7(c$ 0.21, MeOH); UV (MeOH) $\lambda_{\max }(\log \varepsilon): 217$ (3.94) nm; IR (KBr) $\nu_{\max } 3432,2960,2930,1731,1645,1126 \mathrm{~cm}^{-1}$; positive ESIMS $\mathrm{m} /$ $z 489[\mathrm{M}+\mathrm{Na}]^{+}$, HREIMS $m / z 489.2454[\mathrm{M}+\mathrm{Na}]^{+}$(calcd for $\left.\mathrm{C}_{25} \mathrm{H}_{38} \mathrm{O}_{8} \mathrm{Na}, 489.2459\right) ;{ }^{1} \mathrm{H}$ and ${ }^{13} \mathrm{C}$ NMR data, see Tables 1 and 3.

3.4.2 Patriscabioin B (2). Light yellow oil. $[\alpha]_{\mathrm{D}}^{25}-36.9(c$ 0.12, MeOH); UV (MeOH) $\lambda_{\max }(\log \varepsilon): 218$ (3.87) nm; IR (KBr) $\nu_{\max } 3453,2960,2930,1732,1646,1125 \mathrm{~cm}^{-1}$; positive ESIMS $\mathrm{m} /$ $z 489[\mathrm{M}+\mathrm{Na}]^{+}$, HREIMS $m / z 489.2462[\mathrm{M}+\mathrm{Na}]^{+}$(calcd for $\left.\mathrm{C}_{25} \mathrm{H}_{38} \mathrm{O}_{8} \mathrm{Na}, 489.2459\right) ;{ }^{1} \mathrm{H}$ and ${ }^{13} \mathrm{C}$ NMR data, see Tables 1 and 3.

3.4.3 Patriscabioin C (3). Light yellow oil. $[\alpha]_{\mathrm{D}}^{23}-14.0(c$ 0.39, MeOH); UV (MeOH) $\lambda_{\max }(\log \varepsilon): 207$ (3.41) nm; IR (KBr) $\nu_{\max } 3428,2961,2931,1734,1665,1191 \mathrm{~cm}^{-1}$; positive ESIMS $\mathrm{m} /$ $z 491[\mathrm{M}+\mathrm{Na}]^{+}$, HREIMS $m / z 491.2607[\mathrm{M}+\mathrm{Na}]^{+}$(calcd for $\left.\mathrm{C}_{25} \mathrm{H}_{40} \mathrm{O}_{8} \mathrm{Na}, 491.2602\right) ;{ }^{1} \mathrm{H}$ and ${ }^{13} \mathrm{C}$ NMR data, see Tables 1 and 3 .

3.4.4 Patriscabioin D (4). Light yellow oil. $[\alpha]_{\mathrm{D}}^{24}-39.3(c$ 0.37, MeOH); UV (MeOH) $\lambda_{\max }(\log \varepsilon): 217$ (4.05) nm; IR (KBr) $\nu_{\max }$ 3432, 2958, 2932, 1731, 1648, 1408, $1127 \mathrm{~cm}^{-1}$; positive ESIMS $m / z 405[\mathrm{M}+\mathrm{Na}]^{+}$, HREIMS $m / z 405.1889[\mathrm{M}+\mathrm{Na}]^{+}$(calcd for $\left.\mathrm{C}_{20} \mathrm{H}_{30} \mathrm{O}_{7} \mathrm{Na}, 405.1884\right) ;{ }^{1} \mathrm{H}$ and ${ }^{13} \mathrm{C}$ NMR data, see Tables 1 and 3 .

3.4.5 Patriscabioin E (5). Light yellow oil. $[\alpha]_{\mathrm{D}}^{24}-70.4(c$ 0.09, MeOH); UV (MeOH) $\lambda_{\max }(\log \varepsilon): 218$ (4.11) nm; IR (KBr) $\nu_{\max }$ 3436, 2961, 2930, 1734, 1647, 1381, 1251, $1127 \mathrm{~cm}^{-1}$; positive ESIMS $m / z 447[\mathrm{M}+\mathrm{Na}]^{+}$, HREIMS $m / z 447.1983[\mathrm{M}+$ $\mathrm{Na}]^{+}$(calcd for $\mathrm{C}_{22} \mathrm{H}_{32} \mathrm{O}_{8} \mathrm{Na}, 447.1989$ ); ${ }^{1} \mathrm{H}$ and ${ }^{13} \mathrm{C}$ NMR data, see Tables 1 and 3 .

3.4.6 Patriscabioin F (6). Light yellow oil. $[\alpha]_{\mathrm{D}}^{25}-6.6(c 0.33$, $\mathrm{MeOH}) ; \mathrm{UV}(\mathrm{MeOH}) \lambda_{\max }(\log \varepsilon): 223$ (2.91) nm; IR (KBr) $\nu_{\text {max }}$ $3430,2925,2856,1630,1384,1031 \mathrm{~cm}^{-1}$; positive ESIMS $\mathrm{m} / z 620$ $[\mathrm{M}+\mathrm{K}]^{+}$, HREIMS $m / z 659.3924[\mathrm{M}+\mathrm{K}]^{+}$(calcd for $\mathrm{C}_{36} \mathrm{H}_{60} \mathrm{O}_{8} \mathrm{~K}$, 659.3920); ${ }^{1} \mathrm{H}$ and ${ }^{13} \mathrm{C}$ NMR data, see Tables 2 and 3.

3.4.7 Patriscabioin G (7). Light yellow oil. $[\alpha]_{\mathrm{D}}^{24}-20.7(c$ 0.15, MeOH); UV (MeOH) $\lambda_{\max }(\log \varepsilon): 220$ (3.64) nm; IR (KBr) $\nu_{\max }$ 3427, 2930, 1726, 1638, 1384, 1128, $1085 \mathrm{~cm}^{-1}$; positive ESIMS m/ $z 377[\mathrm{M}+\mathrm{Na}]^{+}$, HREIMS $m / z$ 377.1934 $[\mathrm{M}+\mathrm{Na}]^{+}$(calcd for $\left.\mathrm{C}_{19} \mathrm{H}_{30} \mathrm{O}_{6} \mathrm{Na}, 377.1935\right) ;{ }^{1} \mathrm{H}$ and ${ }^{13} \mathrm{C}$ NMR data, see Tables 2 and 3.

3.4.8 Patriscabioin $\mathbf{H}$ (8). Light yellow oil. $[\alpha]_{\mathrm{D}}^{24}-17.0(c$ 0.20, MeOH); UV (MeOH) $\lambda_{\max }(\log \varepsilon): 217$ (3.41) nm; IR (KBr) $\nu_{\max } 3431,2963,2929,1729,1633,1382,1125 \mathrm{~cm}^{-1}$; positive ESIMS $m / z 505[\mathrm{M}+\mathrm{Na}]^{+}$, HREIMS $m / z 505.2407[\mathrm{M}+\mathrm{Na}]^{+}$(calcd for $\left.\mathrm{C}_{25} \mathrm{H}_{38} \mathrm{O}_{9} \mathrm{Na}, 505.2408\right) ;{ }^{1} \mathrm{H}$ and ${ }^{13} \mathrm{C}$ NMR data, see Tables 2 and 3 .

3.4.9 Patriscabioin I (9). Light yellow oil. $[\alpha]_{\mathrm{D}}^{24}-21.4(c 0.12$, $\mathrm{MeOH}) ; \mathrm{UV}(\mathrm{MeOH}) \lambda_{\max }(\log \varepsilon): 248$ (3.56) nm; IR (KBr) $\nu_{\max }$ 3421, 2928, 1670, 1627, 1385, $1188 \mathrm{~cm}^{-1}$; positive ESIMS m/z 251 $[\mathrm{M}+\mathrm{Na}]^{+}$, HREIMS $m / z 251.0885[\mathrm{M}+\mathrm{Na}]^{+}$(calcd for $\mathrm{C}_{11} \mathrm{H}_{16} \mathrm{O}_{5} \mathrm{Na}$, 251.0890); ${ }^{1} \mathrm{H}$ and ${ }^{13} \mathrm{C}$ NMR data, see Tables 2 and 3.

3.4.10 Patriscabioin J (10). Light yellow oil. $[\alpha]_{\mathrm{D}}^{24}+11.7(c$ 0.37, MeOH); UV (MeOH) $\lambda_{\max }(\log \varepsilon): 216$ (2.24) nm; IR (KBr) $\nu_{\text {max }}$ 3417, 2928, 1735, 1629, 1384, $1121 \mathrm{~cm}^{-1}$; positive ESIMS m/z 207 $[\mathrm{M}+\mathrm{Na}]^{+}$, HREIMS $m / z 207.0991[\mathrm{M}+\mathrm{Na}]^{+}$(calcd for $\mathrm{C}_{10} \mathrm{H}_{16} \mathrm{O}_{3} \mathrm{Na}$, 207.0992); ${ }^{1} \mathrm{H}$ and ${ }^{13} \mathrm{C}$ NMR data, see Tables 2 and 3.

3.4.11 Patriscabiobisin A (11). Light yellow oil. $[\alpha]_{\mathrm{D}}^{24}-93.3$ (c 0.04, MeOH); UV (MeOH) $\lambda_{\max }(\log \varepsilon): 217$ (4.24) nm; IR (KBr) $\nu_{\max } 3435,2960,2928,1731,1644,1127,1090 \mathrm{~cm}^{-1}$; positive ESIMS $m / z 567[\mathrm{M}+\mathrm{Na}]^{+}$, HREIMS $m / z 567.2567[\mathrm{M}+\mathrm{Na}]^{+}$(calcd for $\left.\mathrm{C}_{30} \mathrm{H}_{40} \mathrm{O}_{9} \mathrm{Na}, 567.2565\right) ;{ }^{1} \mathrm{H}$ and ${ }^{13} \mathrm{C}$ NMR data, see Table 4 .

3.4.12 Patriscabiobisin B (12). Light yellow oil. $[\alpha]_{\mathrm{D}}^{24}-45.0$ (c 0.08, MeOH); UV (MeOH) $\lambda_{\max }(\log \varepsilon): 219$ (3.69) nm; IR (KBr) $\nu_{\max } 3422,2928,1730,1643,1383,1125,1093 \mathrm{~cm}^{-1}$; positive ESIMS $m / z 567[\mathrm{M}+\mathrm{Na}]^{+}$, HREIMS $m / z 567.2562[\mathrm{M}+\mathrm{Na}]^{+}$(calcd for $\left.\mathrm{C}_{30} \mathrm{H}_{40} \mathrm{O}_{9} \mathrm{Na}, 567.2565\right) ;{ }^{1} \mathrm{H}$ and ${ }^{13} \mathrm{C}$ NMR data, see Table 4.

3.4.13 Patriscabiobisin C (13). Light yellow oil. $[\alpha]_{\mathrm{D}}^{24}-31.9$ (c 0.03, MeOH); UV (MeOH) $\lambda_{\max }(\log \varepsilon): 247$ (3.82), 202 (3.66) nm; IR (KBr) $\nu_{\max } 3431,2929,1625,1384,1121,1077$ $\mathrm{cm}^{-1}$; positive ESIMS $\mathrm{m} / z 447[\mathrm{M}+\mathrm{K}]^{+}$, HREIMS $\mathrm{m} / \mathrm{z} 447.1418$ $[\mathrm{M}+\mathrm{K}]^{+}$(calcd for $\left.\mathrm{C}_{21} \mathrm{H}_{28} \mathrm{O}_{8} \mathrm{~K}, 447.1416\right) ;{ }^{1} \mathrm{H}$ and ${ }^{13} \mathrm{C}$ NMR data, see Table 4 .

\subsection{Computational studies}

CHARMM force field and DFT/TDDFT calculations were performed with Discovery Studio 4.0 and the Gaussian 09 program 
package, respectively. ${ }^{20}$ A conflex conformational search generated low-energy conformers within a $20 \mathrm{kcal} \mathrm{mol}^{-1}$ energy window that were subjected to geometry optimization using DFT without imposing any symmetry constraints at the B3LYP/ 6-31G(d) level. Frequency calculations were carried out at the same level to verify that the molecular structures were true minima. The calculated ECD spectra were generated by the program SpecDis2 using a Gaussian band shape with an exponential half-width of $0.3 \mathrm{eV}$ from the dipole-length dipolar and rotational strengths. ${ }^{21}$

\subsection{Acetylcholinesterase inhibitory activity}

The acetylcholinesterase (AChE) inhibitory activities of the isolated compounds were assayed by the spectrophotometric method developed by Ellman et al. ${ }^{22}$ with slight modifications. $S$-Acetylthiocholine iodide, $S$-butyrylthiocholine iodide, 5, $5^{\prime}$ dithio-bis-(2-nitrobenzoic) acid (DTNB, Ellman's reagent), and acetylcholinesterase derived from human erythrocytes were purchased from Sigma Chemical. The compounds were dissolved in DMSO. The reaction mixture (totally $200 \mu \mathrm{L}$ ) containing phosphate buffer ( $\mathrm{pH} 8.0)$, test compound $(50 \mu \mathrm{M})$, and acetyl cholinesterase $\left(0.02 \mathrm{U} \mathrm{mL}^{-1}\right)$, was incubated for $20 \mathrm{~min}$ $\left(37^{\circ} \mathrm{C}\right)$. Then, the reaction was initiated by the addition of $40 \mu \mathrm{L}$ of solution containing DTNB (0.625 mM) and acetylthiocholine iodide $(0.625 \mathrm{mM})$ for the AChE inhibitory activity assay, respectively. The hydrolysis of acetylthiocholine was monitored at $405 \mathrm{~nm}$ every 30 seconds for one hour. Tacrine was used as a positive control with a final concentration of $0.333 \mu \mathrm{M}$. All these actions were performed in triplicate. The percentage inhibition was calculated as follows: \% inhibition $=(E-S) / E \times$ 100 ( $E$ is the activity of the enzyme without test compound and S is the activity of enzyme with test compound).

\subsection{Cytotoxicity assays}

The following human tumor cell lines were used: HL-60, SMMC7721, A-549, MCF-7, and SW-480. The cells were obtained from ATCC (Manassas, VA, USA). All the cells were cultured in RPMI1640 or DMEM medium (Hyclone, Logan, UT, USA), supplemented with $10 \%$ fetal bovine serum (Hyclone) at $37{ }^{\circ} \mathrm{C}$ in a humidified atmosphere with $5 \% \mathrm{CO}_{2}$. Cell viability was assessed by conducting colorimetric measurements of the amount of insoluble formazan formed in living cells based on the reduction of 3-(4,5-dimethylthiazol-2-yl)-5 (3-carboxymethoxyphenyl)-2-(4sulfophenyl)-2H-tetrazolium (MTS) (Sigma, St. Louis, MO, USA). ${ }^{23}$ Briefly, $100 \mu \mathrm{L}$ of adherent cells were seeded into each well of a 96well cell culture plate and allowed to adhere for $12 \mathrm{~h}$ before drug addition, while suspended cells were seeded just before drug addition, both with an initial density of $1 \times 10^{5}$ cells per $\mathrm{mL}$ in 100 $\mu \mathrm{L}$ medium. Each tumor cell line was exposed to the test compound at various concentrations in triplicate for $48 \mathrm{~h}$, with cisplatin and paclitaxel (Sigma) as positive controls. After the incubation, MTS $(100 \mu \mathrm{g})$ was added to each well, and the incubation continued for $4 \mathrm{~h}$ at $37^{\circ} \mathrm{C}$. The cells were lysed with $100 \mu \mathrm{L}$ of $20 \%$ SDS-50\% DMF after removal of $100 \mu \mathrm{L}$ medium. The optical density of the lysate was measured at $490 \mathrm{~nm}$ in a 96-well microtiter plate reader (Bio-Rad 680). The $\mathrm{IC}_{50}$ value of each compound was calculated by Reed and Muench's method. ${ }^{24}$

\section{Conclusions}

In conclusion, we have isolated and characterized 13 new and 7 known iridoids from the EtOAc extract of $P$. scabiosaefolia. Among these, compounds $\mathbf{1 1}$ to $\mathbf{1 3}$ are the first reported bisiridoids. Several of the new compounds exhibited moderate inhibitory activities on AChE and moderate cytotoxic activities. This contribution enriches our knowledge of iridoids and their bioactivities.

\section{Acknowledgements}

The authors are grateful to the staff of the analytical group of the State Key Laboratory of Phytochemistry and Plant Resources in West China, the Kunming Institute of Botany, Chinese Academy of Sciences, for measurements of all spectra. This work was funded by the Natural Science Foundation of Yunnan Province, China (no. 2015FB168, 2015 HB093 and the provincial academician free exploration project).

\section{Notes and references}

1 B. Dinda, S. Debnath and Y. Harigaya, Chem. Pharm. Bull, 2007, 55, 159.

2 B. Dinda, S. Debnath and Y. Harigaya, Chem. Pharm. Bull., 2007, 55, 689.

3 B. Dinda, D. R. Chowdhury and B. C. Mohanta, Chem. Pharm. Bull., 2009, 57, 765.

4 B. Dinda, S. Debnath and R. Banik, Chem. Pharm. Bull., 2011, 59, 803.

5 S. R. Jensen, B. J. Nielsen and R. Dahlgren, Bot. Not., 1975, 128, 148.

6 J. S. Kim and S. S. Kang, Nat. Prod. Sci., 2013, 19, 77.

7 X. M. Gao, D. Q. Zhang and J. J. Zhang, Applied Illustrated Compendium of Materia Medica, Foreign Languages Press, Beijing, 2006, vol. 1, p. 164.

8 F. W. Dong, Z. K. Wu, L. Yang, C. T. Zi, D. Yang, R. J. Ma, Z. H. Liu, H. R. Luo, J. Zhou and J. M. Hu, Phytochemistry, 2015, 118, 51.

9 S. J. Wang, X. Q. Qiu, J. Y. Zhu, X. Q. Ma, B. Lin, C. J. Zheng and L. P. Qin, Helv. Chim. Acta, 2014, 97, 722.

10 P. W. Thies, Tetrahedron Lett., 1970, 35, 3087.

11 S. Lin, T. Chen, X. H. Liu, Y. H. Shen, H. L. Li, L. Shan, R. H. Liu, X. K. Xu, W. D. Zhang and H. Wang, J. Nat. Prod., 2010, 73, 632.

12 Y. Zhang, Y. Lu, L. Zhang, Q. T. Zheng, L. Z. Xu and S. L. Yang, J. Nat. Prod., 2005, 68, 1131.

13 I. Kouno, I. Yasuda, H. Mizoshiri, T. Tanaka, N. Marubayashi and D. M. Yang, Phytochemistry, 1994, 37, 467.

14 Y. M. Xu, S. P. McLaughlin and A. A. L. Gunatilaka, J. Nat. Prod., 2007, 70, 2045.

15 S. Popov, N. Handjieva and N. Marekov, Phytochemistry, 1974, 13, 2815. 
16 J. L. Jin, S. Lee, Y. Y. Lee, J. E. Heo, J. M. Kim and H. S. YunChoi, Planta Med., 2005, 71, 578.

17 S. Georg and V. Joerg, Arch. Pharm., 1985, 318, 515.

18 N. E. Slatkin and M. Rhiner, J. Supportive Oncol., 2003, 1, 53. 19 A. Monks, D. Scudiero, P. Skehan, R. Shoemaker, K. Paull, D. Vistica, C. Hose, J. Langley, P. Cronise and A. VaigroWolff, J. Natl. Cancer Inst., 1991, 83, 757.

20 M. J. Frisch, G. W. Trucks, H. B. Schlegel, G. E. Scuseria, M. A. Robb, J. R. Cheeseman, G. Scalmani, V. Barone, B. Mennucci, G. A. Petersson, H. Nakatsuji, M. Caricato, X. Li, H. P. Hratchian, A. F. Izmaylov, J. Bloino, G. Zheng, J. L. Sonnenberg, M. Hada, M. Ehara, K. Toyota, R. Fukuda, J. Hasegawa, M. Ishida, T. Y. Nakajima, O. Honda, H. Kitao, T. Nakai, T. Vreven, J. A. Montgomery Jr, J. E. Peralta, F. Ogliaro, M. Bearpark, J. J. Heyd, E. Brothers, K. N. Kudin, V. N. Staroverov, T. Keith, R. Kobayashi, J. Normand, K. Raghavachari, A. Rendell,
J. C. Burant, S. S. Iyengar, J. Tomasi, M. Cossi, N. Rega, J. M. Millam, M. Klene, J. E. Knox, J. B. Cross, V. Bakken, C. Adamo, J. Jaramillo, R. Gomperts, R. E. Stratmann, O. Yazyev, A. J. Austin, R. Cammi, C. Pomelli, J. W. Ochterski, R. L. Martin, K. Morokuma, V. G. Zakrzewski, G. A. Voth, P. Salvador, J. J. Dannenberg, S. Dapprich, A. D. Daniels, O. Farkas, J. B. Foresman, J. V. Ortiz, J. Cioslowski and D. J. Fox, Gaussian 09, Revision C.01, Gaussian, Inc., Wallingford, CT, 2010.

21 T. Bruhn, A. Schaumlöffel, Y. Hemberger and G. Bringmann, Chirality, 2013, 25, 243.

22 G. L. Ellman, K. D. Courtney, V. J. Andres and R. M. Featherstone, Biochem. Pharmacol., 1961, 7, 88.

23 A. Monks, D. Scudiero, P. Skehan, R. Shoemaker, K. Paull, D. Vistica, C. Hose, J. Langley, P. Cronise and A. VaigroWolff, J. Natl. Cancer Inst., 1991, 83, 757.

24 L. J. Reed and H. Muench, Am. J. Hyg., 1938, 27, 493. 